\title{
A RETÓRICA NO PURGATóRIO DE GIL VICENTE
}

\section{Rhetoric in the Purgatory of Gil Vicente}

\author{
Profa. Dra. Maria do Amparo Tavares Maleval \\ (Professora Aposentada da UFF e da UERJ) \\ Profa. Voluntária do Programa de Pós-Graduação em Letras da UERJ \\ Pesquisadora Visitante - PAPD/UERJ \\ Bolsista de Produtividade em pesquisa do $\mathrm{CNPq}$ \\ ORCID: https://orcid.org/0000-0002-5766-3900 \\ E-mail: mamparomaleval@gmail.com
}

Recebido em: 11/07/2020

Aprovado em: 16/09/2020

\begin{abstract}
Resumo: Análise do Purgatório de Gil Vicente, tendo por base a orientação da retórica no que concerne ao tipo de discurso reproduzido na peça, de dominância judicial, bem como aos elementos persuasivos nela presentes, desde a escolha da matéria na inventio aos processos formais da sua expressão, na dispositio e na elocutio. Seguindo essa orientação, e comprovando-lhe a eficácia, foram relevados o contexto de produção e de representação da obra, vincadamente religioso e no qual eram correntes a ideia tripartite do Além, a de julgamento após a morte e da necessidade de práticas virtuosas e fé para o alcance da salvação eterna. Isto sem desprezar, no estudo da linguagem e das figuras presentes nos diálogos, os elementos de comicidade que provocam o riso, maneira de distensão do auditório para com mais leveza apreender a gravidade do assunto que se coloca em cena.
\end{abstract}

Palavras-chave: Retórica; Religião; Quinhentismo; Teatro; Gil Vicente.

Abstract: Analysis of Gil Vicente's work Purgatório, based on rhetorical guidance regarding the type of speech reproduced in the play, of judicial predominance, as well as the persuasive elements present in it, from the choice of the matter in the inventio to the formal processes of its expression, in the dispositio and the elocutio. Following this orientation and proving its effectiveness, was relevant the context work's production and reception, a strongly religious context in which the tripartite idea of the Hereafter, that of judgment after death and the need for virtuous practices and faith for the reach of eternal salvation, were current. This without neglecting, in the study of language and figures present in the character's dialogues, the elements of humor that provoke laughter, a way of distension the audience to more lightly apprehend the gravity of the subject that arises on the scene.

Keywords: Rhetoric; Religion; $16^{\text {th }}$ century; Theater; Gil Vicente. 
O Auto do Purgatório, do grande dramaturgo quinhentista português Gil Vicente ${ }^{1}$, foi, segundo a didascália inicial, peça "representada à muito devota e católica rainha dona Lianor no Hospital de Todolos Santos da cidade de Lisboa, nas matinas do Natal [...] de 1518" (VICENTE, 2002, p. 243). Reinava em Portugal D. Manuel, o Venturoso, herdeiro de um reino que na ocasião era o mais rico da Cristandade. Irmão da viúva de D. João II, D. Leonor, que o ajudou a se entronizar, esta continuou a ter grande prestígio em sua corte, substituindo-o algumas vezes no trono aquando das suas viagens. Cognominada Rainha Velha, extremamente religiosa, pertencia D. Leonor à Ordem Terceira de S. Francisco e notabilizou-se pelas muitas obras de caridade que realizou, uma delas a Misericórdia de Lisboa. Foi a grande mecenas de Gil Vicente e, como indica José Camões (1993, p. 3), Purgatório foi a última peça em que a rubrica indica ter sido representada para ela, sendo possível que ainda tenha assistido o Auto da Glória no ano seguinte, em 1519 antes de falecer, em 1525.

Este foi, em síntese, o contexto de produção e de recepção do auto que escolhemos para análise, uma das obras de devoção vicentinas, bem apropriado a comprazer a uma franciscana rainha, sua principal destinatária. Importa destacar que o mesmo se endereçou às matinas do Natal de $1518^{2}$, isto é, à primeira hora canônica do 25 de dezembro, sendo, pois, representado logo em seguida ao ofício litúrgico de celebração do nascimento do Redentor. A data é a mais festiva, mas não o lugar em que foi encenado - um hospital -, nem a atmosfera circundante, dado que 1518 foi tempo de peste em Lisboa. Portanto, o auto foi direcionado primeiramente a pessoas enfermas, preocupadas com a doença e temerosas ou conscientes da proximidade da morte.

À primeira vista poderia parecer inoportuno que, encomendado para uma data religiosa tão festiva como o Natal, que comemora o nascimento do Redentor, chame à cena um julgamento após a morte, colocando em evidência o caráter desta, inexorável e igualitária, e a destinação do homem ao Inferno ou ao Paraíso. Mas trata-se do Purgatório, esse antelugar no qual a alma se purificaria para alcançar o Paraíso. Espaçotempo, pois, de sofrimento mas também de esperança, já que a Glória é destinação garantida aos que aí se encontram.

Aliás, é muito comum nas peças natalinas, e outras, de Gil Vicente, mesmo as representadas em contexto mais ameno $^{3}$, que, ao lado da comemoração da vida, se destaque a finitude da existência humana e da necessidade de uma vida regrada pelos bons costumes e pela fé para o alcance da salvação espiritual, como preconiza o cristianismo. E, no caso presente, o Purgatório, esse terceiro lugar do Além que a partir do século XII a Igreja instituiu, consubstancializa a esperança de salvação da alma.

\section{A Retórica e o discurso judiciário}

A peça Purgatório apresenta um julgamento após a morte de personagens hegemonicamente campesinos, que buscam se defender da sedução e das acusações do Diabo diante de um Anjo, juiz que decide sobre quem embarcará para a Glória, destino desejado por todos os mortos. Tal é o enredo também dos autos vicentinos das Barcas do Inferno (1517) e da Glória (1519) ${ }^{4}$, diferenciando-se destes, que são destinados a comemorações outras que não o Natal, por alguns aspectos de interlocução dos personagens, como o uso de linguagem adequada ao extrato social dos réus, urbanos e 
medianos no primeiro caso e poderosos na terra no segundo. Aliás, foram considerados pela crítica uma "trilogia das Barcas". Mas são duas, e não três, as embarcações, dado que o purgatório é muito mais um tempo de purgação, um lugar transitório onde se fica temporariamente para o alcance do Paraíso no Juízo Final ou até quando Deus quiser, segundo a Igreja. São, pois, três "autos com barcas" (CAMÕES, 1993, p. 10), mas restritas a duas.

Esses autos nos remetem de imediato ao discurso judiciário, que, ao lado dos discursos deliberativo e epidítico, é um dos três gêneros de discurso apontados por Aristóteles ([s.d.]. p. 43) em sua obra sobre a Retórica. Nele se defrontam a acusação e a defesa, tendo em vista o alcance de um dictamen favorável do juiz, com base no exame de fatos passados apresentados como provas, com a finalidade de se alcançar uma solução justa. Tem como principal recurso o entimema, silogismo não rigoroso e incompleto, lançando mão de argumentos apenas prováveis para efeito persuasivo.

Contudo, o filósofo observava que os discursos podem se amalgamar, de forma que principalmente o gênero deliberativo pode abarcar ou se imiscuir nos demais, notadamente no judiciário (ARISTÓTELES, [s.d.], p. 43). Isto porque ambos têm em vista uma mudança pragmática da situação vigente, o que não é essencial no gênero epidítico. Senão vejamos: o discurso deliberativo ou político constitui discussão e aconselhamento a respeito de uma ação futura, objetivando demonstrar a sua utilidade ou prejuízo; seu principal recurso é o exemplo, tendo em vista formar um modelo a ser seguido ou evitado. Já o gênero epidítico, tem por escopo o elogio ou a censura de alguém ou algo, fundamentando-se principalmente no tempo presente e tendo como recurso primordial a amplificação, figura que desenvolve o fato ou idéia em discussão acrescentando-lhe pormenores, comparações, etc. ${ }^{5}$

O auto Purgatório, embora de saída se apresente como discurso judicial, já que de um julgamento se trata, tem muito de deliberativo, pois, através da discussão sobre a culpa das personagens, emerge o aconselhamento aos assistentes, da necessidade de se levar uma vida cristãmente virtuosa para o alcance do Paraíso no outro mundo.

Para a análise do auto, levaremos em conta que a Retórica, enquanto estudo das técnicas de persuasão dos discursos, indica as suas fases de elaboração: inventio, dispositio, elocutio, memoria e pronuntiatio ${ }^{6}$. As três primeiras nos interessam mais de perto, já que trabalhamos com o texto - com a sua matéria e elaboração - e não com a representação, que requer memorização e pronunciação adequada.

\section{Sobre a inventio}

Começaremos por observar, no auto, aspectos da inventio, isto é, da descoberta das ideias e argumentos adequados para o discurso persuasivo, em que se destacam os topoi. Trata-se, pois, de um processo de encontro ou recordação dessas ideias, de determinação da matéria do discurso, mas que não invalida o ingenium do orador ou do $\operatorname{artista}^{7}$.

Aponta Lausberg que os pensamentos já se encontrariam (1982, p. 91) "no subconsciente ou na semiconsciência do orador, como copia rerum" (LAUSBERG, 1982, p. 91), por exemplo através dos topoi ou lugares comuns ${ }^{8}$. Tal é, por exemplo, a concepção cristã da vida após a morte no Céu ou no Inferno, e, entre estes, o Purgatório, invenção eclesial do século XII. Ou o tipo de discurso adotado, muito familiar no 
contexto quinhentista (e não só) - o judiciário. A este voltaremos adiante, ao examinarmos os processos de elaboração do discurso vicentino. Por agora nos ateremos ao entendimento da morte e da vida após ela no imaginário coletivo da época de Gil Vicente.

Le Goff acentua que o Além do cristianismo "recolhe as heranças vindas do paganismo greco-romano, das religiões e crenças orientais, do Antigo Testamento e do judaísmo, mas é fundado sobretudo nos Evangelhos e no Novo Testamento em geral" (LE GOFF, 2002, p. 21). Interessa-nos especialmente este último, em que se fundamenta o cristianismo, religião imperante no contexto em que se inseria Gil Vicente. Vamos a ele, a partir das indicações do medievalista francês, que nos servem de orientação, e sua comprovação na edição que utilizamos da Bíblia ([1981]).

Nos Evangelhos, Mateus $(25,31-46)$ trata do Juízo Final, da Parúsia, em que o Deus Filho, "reunidas em sua presença todas as nações [...] separará os homens uns dos outros" (BÍBLIA, [1981], p. 1316), premiará os justos com o Reino dos Céus e condenará os maus ao fogo eterno. Lucas $(16,22-26)$ apresenta parábolas que ilustram a destinação dos maus e dos bons após a morte. Por exemplo, o pobre Lázaro é "levado pelos anjos ao seio de Abrahão" (BÍBLIA, [1981], p. 1366) - ao Limbo dos Patriarcas, pois -, ao passo que o mau rico, de quem Lázaro comia os restos dos banquetes, encontra-se "no inferno, em meio a tormentos" (BÍBLIA, [1981], p. 1366). Para Le Goff (2002, p. 24), "este texto é a certidão de nascimento do Inferno cristão". Acrescente-se que às crianças e aos que a elas se igualarem é destinado o "Reino de Deus" (BÍBLIA, [1981], p. 1368). E João (5, 25-29), fala da ressurreição de "de vida" para os que praticaram o bem e de "condenação" para os que praticaram o mal, tendo por Juiz o Filho de Deus (BÍBLIA, [1981], p. 1390).

$\mathrm{Na}$ segunda epístola de Paulo aos Coríntios $(12,4)$, é mencionada a visão do Paraíso, de um "homem em Cristo [...] arrebatado ao terceiro céu" (BÍBLIA, [1981, p. 1517). E, no Apocalipse (2, 7), o Paraíso como destino dos que não sucumbiram aos pecados: "Ouça o que o Espírito diz às Igrejas: ao vencedor, conceder-lhe-ei comer da árvore da vida que está no paraíso de Deus" (BÍBLIA, [1981], p. 1610).

Para Le Goff (2002, p. 24), os apóstolos Pedro e Paulo apresentaram "o evento mais espetacular concernente ao Inferno": a descida de Cristo ao Hades. Segundo Pedro, retomando na sua primeira Epístola (3, 18- 22) indicação anterior, dos Atos dos Apóstolos, Jesus, morto na carne mas "vivificado no espírito, [...] foi também pregar aos espíritos em prisão" (BÍBLIA, [1981, p. 1586). E Paulo, na Epístola aos Romanos (10, 5-13), ao tratar da justiça que provém da lei mosaica e da que provém da fé, também se refere à ressurreição de Jesus, elevado do mundo dos mortos.

Essa descida ao mundo dos mortos, na interpretação de Le Goff, "faz de Cristo o sucessor dos deuses e heróis (Gilgamesh, por exemplo, na mitologia oriental) que são levados a vencer a morte em seu antro" (LE GOFF, 2002, p. 24). E Cristo se faz "o deus vitorioso e libertador que funda o cristianismo como religião de vida" (LE GOFF, 2002, p. 24). Disse Paulo aos romanos (10, 9-10): "se confessares com tua boca que Jesus é o Senhor e creres em teu coração que Deus o ressuscitou dentre os mortos, serás salvo. Pois quem crê de coração obtém a justiça, e quem confessa com a boca, a salvação" (BÍBLIA, [1981, p. 1483).

Tal imaginário seria, nos primeiros séculos da Era Cristã, desenvolvido em textos apócrifos judaicos e cristãos, severamente condenados por Santo Agostinho e outros 
padres da Igreja. E foi profusamente explorado na iconografia e na literatura do medievo (e não só), notadamente nas "visões" de monges e personagens importantes, dentre estes até mesmo um imperador, Carlos, o Gordo, no século IX.

Essas (re)criações por vezes apresentavam elementos do folclore dito pagão, notadamente dos povos celtas e germânicos. Presentes "nas descrições do Purgatório, nos séculos XII e XIII, suscitaram reservas de teólogos de alto nível intelectual, como Santo Tomás de Aquino, que recusavam esse imaginário "popular" e pagão" (LE GOFF, 2002, p. 27).

As viagens ao Além tiveram suas principais raízes na mitologia do Oriente Médio, e também do Egito, bem como em obras épicas da Grécia antiga e de Roma. Por exemplo, na Odisseia de Homero, livro 11, e na Eneida de Virgílio. Esta última foi mais acessível aos homens do medievo. E, no livro sexto, situa na terra o mundo após a morte, ficando à direita, em bifurcação do rio Estige, o Tártaro infernal, lugar de trevas, gemidos e estrondos; e, na bifurcação à direita, os Campos Elíseos, luminoso e aprazível.

Para o cristianismo, o homem, em sua caminhada terrena, estaria predisposto ao erro pelo Pecado Original, e luta contra a carne e os apelos do mundo e do diabo para não cair em pecado, tendo de cultuar as virtudes para não sucumbir aos vícios. Recordemos que as virtudes preconizadas pela Igreja são as morais - na esteira dos antigos como Aristóteles em sua obra Ética a Nicómaco (1979) escrita no século IV a.C -, e as teologais. As morais ou cardeais são a prudência, a justiça, a fortaleza e a temperança. E as teologais são a fé, a esperança e a caridade. Não praticá-las é dar as costas para os Mandamentos judaico-cristãos, que teriam sido entregues por Deus a Moisés no Monte Sinai e registrados no Velho Testamento, no Êxodo e no Deutoronômio 9 . Ressalve-se que, para Aristóteles (1979, p. 44-236), as virtudes morais, assimiladas com pequenas variantes pela Igreja cristã, levam ao Bem e à felicidade ainda em vida, mas devem ser praticadas com equilíbrio, pois tanto o exagero quanto a falta redundam em vícios.

No mundo cristão, a desobediência a tais preceitos implica nos pecados mortais que levam ao Inferno, e a sua obediência, ao Paraíso. Entretanto, nos séculos IV-V Santo Agostinho firmou quatro categorias de homens: os completamente bons, destinados ao Paraíso, os completamente maus, enviados ao Inferno, e os não totalmente bons ou maus. Isso daria azo à noção de pecado venial, tal seja: os que morressem com pecados leves obteriam penas purificadoras e não a condenação pura e simples.

No final do século VI, o papa Gregório Magno imaginara que esses lugares purgatórios se encontrariam na terra. Mas, como indica Le Goff, "a solução mais frequente foi distinguir no Inferno uma geena superior, de onde se poderia, depois de um tempo mais ou menos longo de suplícios e provação, subir ao Paraíso" (LE GOFF, 2002, p. 31).

Temos, pois, que na segunda metade do século XII a Igreja instituiu esse terceiro lugar, intermediário e não eterno, na geografia do Além: o Purgatório, que se esvaziaria no Juízo Final, quando todos os que nele se encontrassem seriam levados ao Paraíso. Neste lugar estariam os portadores de pecados veniais, os que em pequeno grau e em algum momento se abeiraram dos pecados capitais - a avareza, a gula, a ira, a luxúria, a preguiça e a soberba -, praticando ações afins como o ciúme e a maledicência, o trabalho feito com displicência e a abstenção de orações, o destempero no falar, etc. 
Em vida, a absolvição desses pecados poderia ser alcançada pela confissão, contrição e penitência. Após a morte, pelos sufrágios - isto é, orações, esmolas e missas pela alma do finado, que os parentes ou amigos encomendavam, mediante pagamento -, como também pela compra de indulgências. Estas se tornaram um comércio crescente da Igreja a partir do século XIII, ao que fizeram frente os reformadores, como Martinho Lutero no século XVI.

Pois bem, Gil Vicente foi contemporâneo dessa reforma protestante que, dentre outras coisas, condenou o Purgatório e a venalidade e manipulação da Igreja por ele proporcionada. Aliás, a Igreja foi criticada em muitos dos seus autos, como, para só citarmos um exemplo, no Auto da Feira ${ }^{10}$, no qual o Diabo, um dos mercadores da feira alegórica, desmascara Roma: "porque the sei a maneira / de seu vender e comprar" (VICENTE, 2002, v. I, p. 167).

No entanto, o dramaturgo tinha por mecenas uma rainha franciscana, e os franciscanos, junto aos dominicanos, como se sabe ordens mendicantes nascidas no início do século XIII, foram grandes difusores dessa concepção eclesial de lugar de purgação, junto aos dois lugares complementares - o Limbo dos Patriarcas, levados por Jesus ao Paraíso aquando da sua descida aos infernos por ocasião da sua morte terrena, e o Limbo das Crianças que morreram sem serem batizadas. Tal concepção, transformada em dogma pela Igreja, lhe assegurava sobre os mortos "um poder de jurisdição que anteriormente pertencia apenas a Deus" (LE GOFF, 2002, p. 32). O Juízo Final correspondia a um julgamento coletivo da alçada exclusiva do Deus Filho, e a este se acrescentava o juízo individual, imediato à morte, que podia ser amortecido pelos sufrágios e indulgências.

Na literatura, posteriormente às já citadas obras Odisseia, de Homero, e Eneida, de Virgílio, destaca-se os Diálogos dos mortos, obra escrita no segundo século da Era Cristã por Luciano de Samósata ${ }^{11}$ e que obteve larga repercussão na Europa. Obra extremamente crítica dos grandes nomes da Antiguidade, dentre estes Aristóteles, que, como sabemos, viveu no século IV a.C, satiriza nos diálogos, por exemplo, a esperteza inútil, a verborreia dos oradores ou filósofos, a gula e, destacadamente, os aduladores e gananciosos. A simpatia dos juízes vai para os que foram vítimas de vicissitudes em vida.

Menipo, escritor grego, sarcástico e burlesco, do século III a.C, e Diógenes, filósofo grego do século III-IV a.C, cognominado o Cínico. são destaques positivos. De Diógenes é o discurso inicial, que abre a série de diálogos. Cérbero, o monstruoso cão tricéfalo mitológico que guarda o acesso ao mundo dos mortos, os avalia da seguinte maneira: "Fostes, ó Menipo, o único verdadeiramente digno da tua raça, tu e Diógenes antes de ti, porque vieram, nem forçados nem empurrados, mas de livre vontade, a rirem-se e mandando a todos que se lixassem" (LUCIANO, 1989, p. 78). Portanto, são elogiados pelo seu destemor, mesmo diante da morte, e pelo riso ferino, que a muitos atingiu.

Nesse espaço de mortos ilustres, históricos, não faltam, pois, os seres mitológicos como, além de Cérbero, Caronte, barqueiro do Hades, que carrega as almas pelos rios Estige e Aqueronte, divisores entre os mundos dos vivos e dos mortos; e Plutão, senhor do mundo subterrâneo ou Inferno. A referência ao Estige e ao Hades são indicações dessa geografia do Além que reverbera no auto vicentino em análise. Com também os temas da morte, inexorável e igualitária, e o da inutilidade dos bens materiais no alémtúmulo, exaltando-se as virtudes morais. 
Já Américo da Costa Ramalho aventara a hipótese de Gil Vicente ter conhecido essa obra "provavelmente através de uma versão latina, pois o nosso comediógrafo sabia mais latim do que se pensa geralmente" (In LUCIANO, 1989, p. 13). E, referendando a posição anterior de Eugénio Asensio, indica que algumas passagens do Auto da Barca da Glória remetem para o Diálogo X da obra de Luciano, estabelecido entre Caronte e Hermes. Indica ainda que os Diálogos se encontravam traduzidos para o latim em 1501, mas havia outra obra que o imitava, o Charon de Giovanni, de 1491, que conheceu quatro impressões antes de 1517, data da Barca do Inferno vicentina. Ambas, portanto, poderiam ter servido de herança ao dramaturgo português.

Na literatura do Ocidente medieval, o exemplo mais famoso de recriação do Além é a Divina Comédia, longo poema épico escrito no início do século XIV d.C pelo grande poeta florentino Dante Alighieri. Apresenta três partes, cada uma com 33 cantos: Inferno, Purgatório e Paraíso, cada um dotado de um espaço de passagem prévio. Dante se constitui personagem guiado, no mundo dos mortos, pelo excelso poeta latino Virgílio, já referido, que viveu no primeiro século a.C e compôs clássicos como a Eneida, já atrás indicada. Nos céus, tem como guia Beatriz, que fora em vida amor platônico do poeta quando adolescente. Símbolo do amor espiritual, tem acesso ao mais alto dos espaços celestiais, habitado pelo Deus uno e trino, que é Amor.

O Inferno e o Purgatório se apresentam de forma cônica, o primeiro com círculos que se vão tornando menores até atingirem a parte mais profunda da terra, onde impera o horrendo Lúcifer, tricéfalo e alado - "Lo 'mperador del doloroso regno" (ALIGUIERI, 1946, p. 133); e o segundo, como uma montanha, espaço de purgação gradativa, de cujo cume se acessa o Paraíso terrestre, o Éden. Deste se vai às moradas siderais, espaço do Belo, do Bem, da Inteligência, do Amor, em cujo ápice se encontra o Deus Todo Poderoso e seus eleitos. Dentre este se destaca Maria, "umile e alta piú che creatura" (ALIGUIERI, 1946, p. 341), na qual o Bem se encontra por inteiro - "tutto s'accoglie in lei" (ALIGUIERI, 1946, p. 343). São, pois, vários os lugares desses espaços principais, de acordo com os pecados mais ou menos graves dos mortos ou as suas virtudes maiores ou menores.

Como na obra de Luciano anteriormente citada, em sua caminhada pelo Além Dante encontra numerosos personagens importantes da Antiguidade, mas também do medievo, como S. Tomás de Aquino, encomiasta de S. Francisco. Este se encontra em um dos mais elevados espaços celestiais, simbolizado pelo sol, sede dos intelectuais e sábios que iluminaram o mundo em vida.

Nessa cosmogonia, também os personagens mitológicos são representados, como, para só citarmos um exemplo, o barqueiro Caronte. Este transporta as almas para o Inferno, que é antecedido por um lugar habitado pelos negligentes, indiferentes e preguiçosos, que, se não praticaram o mal, também não fizeram nenhum bem em vida.

A recepção da obra de Dante em Portugal é perceptível, por exemplo, no Cancioneiro Geral de Garcia de Resende de 1516, indicada por estudiosos como Luca Trifiletti (2016). Deste Cancioneiro Gil Vicente inclusive participou, o que aponta para a possibilidade de ter ele conhecido, pelo menos indiretamente, a famosa obra do poeta italiano.

Para não nos alongarmos mais nesse percurso sobre a matéria que Gil Vicente dispunha para encontrar as ideias adequadas à elaboração do seu auto, mencionaremos apenas as Danças macabras ou Danças da morte ou dos mortos, surgidas no século 
XIV. Por essa época, as guerras e os surtos de fome e pestes dizimaram grande parte da população da Europa, notadamente a Peste Negra, a partir de 1348.

O contato quotidiano com a morte e a consciência de ser ela inexorável e igualitária, e, a partir daí, da precariedade da existência humana, possibilitariam a origem desse gênero, de larga repercussão nas artes do período. Principalmente na pintura, na escultura e na literatura, como também em atividades (para)teatrais, se encontram exemplo dessas danças, nas quais figuram de mãos dadas cadáveres em decomposição e vivos de diversos estamentos, profissões e origens, todos fadados à sepultura, sendo a Morte por vezes representada como uma caveira portando uma foice. Um dos seus registros mais acessíveis é o que se encontra na muito bem conservada pintura da Dança macabra de La Ferté-Loupiére ${ }^{12}$, que remonta ao final do século XV e início do século XVI. Nela se observa, no trecho final, as figuras de um lavrador, um franciscano, uma criança, o clérigo da vila e um ermitão, sendo que o último cadáver faz um gesto teatral de agradecimento dirigido aos que veem a pintura, indicando a possibilidade de representabilidade teatral dessa dança ${ }^{13}$.

A consciência da morte resultou na necessidade de se preparar religiosamente para ela, o que foi assunto de muitos sermões. E, em Portugal, no teatro de Gil Vicente ${ }^{14}$ tal tradição se atualizou. Aliás, no tocante ao juízo após a morte, como Dante, que publicou separadamente as partes da Divina Comédia - Inferno, Purgatório e Paraíso -, encenou as peças em que disto trata também separadamente: em 1517 o Auto da Barca do Inferno, em 1518 o Purgatório e em 1519 a Barca da Glória.

Quase sempre imiscuindo o grotesco em seus autos, Gil Vicente faz coro a obras como os Diálogos dos mortos de Luciano, fazendo-nos pensar ainda nas obras de Hieronymus Bosch, admirável pintor holandês que viveu entre 1450 e 1516. Dentre as suas pinturas mais famosas se encontram, para só citarmos apenas duas em que aparecem o Bem e o Mal, o Céu e o Inferno: Os sete pecados capitais e $O$ Jardim das delícias terrenas. A época de Gil Vicente era, pois, muito preocupada com o Além e com a preparação para a salvação eterna, difundindo-se então os percalços que tornariam esta inviável: os pecados.

\section{Sobre a dispositio e a elocutio}

Passemos a observar como a ideia de julgamento após a morte e de Purgatório, que, como vimos, eram preponderantes no imaginário da época de Gil Vicente, se consubstancializa no auto. Para tanto, examinaremos elementos da dispositio e da elocutio usados na elaboração do mesmo.

A dispositio, constitui a "maneira de dispor as diferentes partes do discurso" (ARISTÓTELES,[s.d.], p. 205), pela escolha e ordenação adequadas à melhor estruturação "dos pensamentos (res), das formulações linguísticas (verba) e das formas artísticas (figurae)" (LAUSBERG, 1982, p. 95). A elocutio, trata do "estilo que se deve empregar" (ARISTÓTELES, [s.d.], p. 205). Ou seja, "é a expressão linguística (verba) dos pensamentos (res) encontrados pela inventio" (LAUSBERG, 1982, p. 115). Liga-se à gramática, "sistema de regras que regulamentam a pureza linguística e idiomática (puritas)" (LAUSBERG, 1982, p. 115), e à retórica, "sistema de regras que garantem o êxito da persuasão" enquanto "ars bene dicendi" (LAUSBERG, 1982, p. 115). Esta às vezes entra em conflito com aquela, dando origem à licencia, que é permitida e que não 
pode ser confundida com o vitium, desvio da puritas idiomática sem justificativa. Importa considerar, com Chaim Perelman e Lucie Olbrechts-Tyteca (1996), que, no exame da elocutio, as figuras do discurso valem ser vistas pelo "efeito, ou um dos efeitos" que têm, na apresentação dos dados, de "impor ou sugerir uma escolha, aumentar a presença ou realizar a comunhão com o auditório" (PERELMAN; O.TYTECA, 1996, p. 195).

Evidentemente que não temos a pretensão de esgotar o exame desses processos de elaboração do discurso no auto vicentino. Indicaremos, sim, alguns exemplos ligados à adequação idiomática e às figuras retóricas, interpretando-lhes os sentidos.

$\mathrm{O}$ auto foi o primeiro ou um dos primeiros a serem escritos em português por Gil Vicente e no qual buscou reconstituir a fala rústica dos campesinos em língua nativa ${ }^{15}$. Aportuguesou, pois, também a linguagem dos rústicos, dado que escrevera em castelhano várias das suas peças, as primeiras delas apresentando pastores falando com traços dialetais do saiaguês, a exemplo das nas églogas pastoris de Juan del Encina ${ }^{16}$.

Inicia-se com três Anjos cantando ${ }^{17}$ um romance, um tipo de composição muito em voga na época, de extração popular e tipicamente hispânica. Muitas vezes anônima, compunha-se de versos de sete sílabas - redondilha maior -, que aliás é a métrica predominante no auto. E fala de remeiros angelicais a serviço do Deus Filho em "barca de grande alegria" (VICENTE, 2002, p. 243), o que nos remete às composições tradicionais chamadas de barcarolas.

Em seguida a esse cântico inicial, entram em cena os personagens principais, a começar pelo Arrais do Inferno e em seguida pelo o Anjo que será o juiz das almas. Seus discursos compõem o prólogo do auto, após o qual irão chegando um a um os defuntos a serem julgados: o Lavrador, a regateira Marta Gil, o Pastor, a Pastora "menina", o Menino "de tenra idade" e o Taful. Hegemonicamente inominados ${ }^{18}$, a única claramente nomeada é Marta Gil, inclusive reconhecida pelo Diabo como tal, como se fora velha conhecida dele. Como adjuvantes se apresentam ainda o Companheiro do Diabo, além dos Anjos cantores. O número de versos do Prólogo e dos diálogos concernentes a cada personagem é superior a 100, diminuindo drasticamente nos relacionados ao Menino, -35 versos apenas -, e voltando a subir um pouco com o Taful, muito embora sem atingir a marca inicial. Essa diminuição tão relevante da cena do menino poderia estar relacionada, muito mais que à dificuldade de decorar as falas caso o mesmo fosse representado por uma criança, pela destinação inquestionável dos pequeninos ao Paraíso, presente no Evangelho de Mateus $(19,14)$, conforme teremos ocasião de observar adiante. Quanto ao Taful, embora ardiloso na argumentação, já estava a priori condenado, por motivo da gravidade dos seus pecados, imperdoáveis.

No prólogo, o Arrais do Inferno é o primeiro a falar, queixando-se da ausência de defuntos no porto e do cansaço de remar, que seria dirimido com uma embarcação maior, na qual poderia levar mais condenados com menos esforço. Esta lhe é muito oportuna, já "que cobiça e simonia / enveja e tirania / nehûa delas afraca" (VICENTE, 2002 , p. 244). Isto é, o número de condenados nunca diminuirá, pois os pecados dominam o mundo, sendo indicados por ele alguns dos mais importantes. Já aí se percebe uma figura, a metonímia, que substitui a causa - os pecados - pelo efeito - os pecadores, cuja destinação é a condenação.

O Anjo, que o sucede em cena, concita a todos para o Paraíso, referindo-se ao Natal como ocasião adequada à salvação: “À glória, à glória senhores / oh que noite 
pera isso [...]" (VICENTE, 2002, p. 244). Sendo o auto, como vimos, destinado às matinas do Natal, essa apóstrofe se estende duplamente, aos personagens e à plateia, configurando-se como uma figura da comunhão - conforme indicam Chaim Perelman e O. -Tyteca (1996, p. 201), "figuras da comunhão são aquelas em que, mediante procedimentos literários, o orador empenha-se em criar ou confirmar a comunhão com o auditório".

São estabelecidas sábias reflexões em seu discurso, a começar pela concepção neoplatônica da vida como sonho: "que vossa vida é sonhar / e a morte é despertar / pera nunca mais dormir / nem acordar" (VICENTE, 2002, p. 244). Sobre as embarcações, contrapõe ao seu "barco seguro" a "má bateira" do Diabo, utilizando adjetivos que acentuam a diferença entre ambas. Alude à "viagem primeira", isto é, ao Auto da Barca do Inferno, representado no ano anterior, mais uma figura da comunhão com o auditório, certamente conhecedor deste auto representado no ano anterior, 1917. E, após frisar o caráter inevitável da morte, de novo se refere à data em que se representa o auto, danosa para o inimigo: "E o batel dos danados / porque naceu hoje Cristo / está c'os remos quebrados / em seco [...]" (VICENTE, 2002, p. 245). Termina sua fala com a incitação às almas, para invocarem a piedade da Mãe de Jesus, "a madre pia / frol de toda perfeição [que neste dia, por motivo do nascimento do seu divino filho] está com tanta alegria" (VICENTE, 2002, p. 245). Como se percebe, Maria é modelo do Belo e do Bem, através da metáfora "frol de toda perfeição".

Novamente discursa o Diabo, com imprecações contra os empecilhos que enfrenta, estando o seu batel "em seco" e o rio congelado (VICENTE, 2002, p. 246). Aparece-lhe um Companheiro que lhe fala serem essas dificuldades procedentes da data que está sendo comemorada: "Mas sabe que este serão / é pera nós grande praga / e trabalhamos em vão / porque a promessa d'Abraão / hoje é paga" (VICENTE, 2002, p. 246). Trata-se de alusão à revelação feita por Deus a Abrahão, no Gênesis $(3,15)$, relativa à desobediência de Eva ao sucumbir à tentação, de que a mulher esmagaria a cabeça da serpente (BÍBLIA, [1981], p.35). Essa prefiguração pode ser entendida como: em uma geração futura, de uma mulher nasceria o Redentor que derrotaria Satanás. Tal é o significado do Natal.

Esses discursos de entes sobrenaturais, barqueiros antagonistas, que compõem o prólogo da peça, interligam por vezes, como vimos, o espaço da ficção com o momento de representação da mesma e com o auditório, através das figuras comentadas. Importa destacar que esses personagens se diferenciam não apenas pelas suas funções e ideias, mas pela linguagem, sendo a do Anjo filosófico-teológica, e, condizente com isto, correta e não vulgar. Já a do Diabo é pragmática, permeada de termos e expressões corriqueiros, principalmente entre os marinheiros, como "Ala ala saca saca", isto é, "vamos, vamos".

Passemos a seguir à observação dos personagens-defuntos, que aparecem não conjuntamente, mas um a um, a começar pelo Lavrador, identificado de saída pela sua linguagem rude. É imediatamente abordado pelo Diabo - aliás sempre o primeiro a abordar a todos -, que, usando registro linguístico semelhante, o manda despir-se e inclusive deixar de lado o arado, fazendo-nos recordar dos Diálogos dos mortos de Luciano, obra atrás referida, em que se destaca a inutilidade de coisas materiais no além-túmulo.

Mas o diabo não o assusta, dado que ao morrer perdera o medo: "Com'eu a morte passei / logo o medo ficou finto" (VICENTE, 2002, 247). E também porque em vida 
agira como homem de bem - "como homem de bô retinto" (VICENTE, 2002, p. 247), não deixando dívidas. Mas o Diabo, como advogado de acusação, o acusa de haver trapaceado em vida, justificando-se o réu por também ter sido vítima de ladrões. Recusando-se a abandonar o arado que trouxera, este é considerado um passaporte para o Céu, configurando-se como metonímia da sua sofrida condição: "que sempre fui perseguido / e vivi mui trabalhado" (VICENTE, 2002, p. 248).

Sarcasticamente o Lavrador chama o Diabo de "pulga de judeu" (VICENTE, 2002, p. 247), metáfora insultuosa que, além de tornar a cena risível, revela o antissemitismo dominante à época. $\mathrm{E}$ os dois continuam zombando-se mutuamente, o que certamente provocaria o riso nos expectadores: se o Diabo ironicamente o chama de "Dom vilão", ele retruca: "E vós dum rosto de fonil / cuidareis que sois alguém?" (VICENTE, 2002, p. 248).

Chamado pelo Anjo, novamente se utiliza do fato de ser Lavrador para merecer o Céu, em antológicos versos, já agora em linguagem elevada: "Nós somos vidas das gentes / e morte das nossas vidas" (VICENTE, 2002, p. 249). Explorado, é tanto o trabalho que não lhe sobra tempo para pecar. Escorraçado pelas suas atitudes consideradas socialmente inapropriadas, é um injustiçado. E, se tudo isto não bastasse para a salvação, apela para o "serão glorioso", que comemora o nascimento do Redentor, que o torna fortalecido e nada amedrontado - "temeroso / nemigalha" (VICENTE, 2002, p. 249). Novamente o elo entre a ficção e a circunstância da representação. Mas o Anjo quer saber sobre os bens que praticara em vida, ao que ele retruca: ia à igreja, dava esmolas, persignava-se toda manhã, sabia rezar o credo. Todavia, o Diabo o acusa de trapacear no dízimo, ao que ele responde com insultos, inclusive de baixo calão, como "fi de puta maldito" (VICENTE, 2002, p. 250). E diz ter feito o reparo desse erro, doando seus bens inclusive a um clérigo e pagando sufrágios pelas almas dos mortos.

O Lavrador, além de aventar provas em benefício próprio, ainda apela para a promessa evangélica: "quem for bautizado e crer / salvus est" (VICENTE, 2002, p. 251). Repare-se na expressão latina salvus est, que não quebra a verossimilhança da situação, dado ser conhecida dos frequentadores dos cultos religiosos, mesmo os mais incultos. Todavia o Anjo lhe dá o veredito: não poderá entrar em sua barca, ficará "purgando nessa ribeira / até que o senhor Deus queira / que te levem pera si / nesta bateira" (VICENTE, 2002, p. 251). E o Lavrador, atrevidamente como sempre, questiona a pena: se há de ir para a Glória, porquê ficar padecendo no Purgatório? Mas em seguida faz uma elevada reflexão, de cariz neoplatônico e com linguagem apropriada para tal, sobre a existência material, enganosa e passageira: "Ó mundo mundo enganado / vida de tão poucos dias / tam breve tempo passado / tu me trouxeste enganado / e me mentias" (VICENTE, 2002, p. 251).

Portanto, vimos até aqui elementos típicos do discurso judicial, com acusação, defesa, réplicas e sentença. Vimos também como a linguagem se adequa às situações, lançando o autor inclusive mão de figuras, ironias, insultos e grosserias provocadores do riso no auditório, que dessa forma se desarma para receber o ensinamento final, enunciado pelo próprio Lavrador, já salvo do Inferno. Em tom de lamento, exproba o mundo e seus perigos, que estorvam a caminhada do homem para o Bem. Tal vitupério, da mesma forma que os elogios, é uma marca dos discursos epidíticos, mas guarda em si um conselho, próprio do discurso deliberativo - no caso, que ninguém se deixe levar pelas seduções mundanas. 
A seguir, focalizaremos, de forma mais ligeira como convém ao momento, os debates dos demais personagens, na ordem em que aparecem no auto.

Marta Gil, a regateira, entra em cena recusando-se, como seu antecessor, a entrar na embarcação do Diabo. Então é por este acusada de "fataxas fazer", que explica da seguinte forma: "Os feitos que feitos leixas / e o povo cheo de queixas" (VICENTE, 2002 , p. 252) - isto é, os maus feitos da regateira deixaram queixosas as vítimas de suas trapaças. Trata-se de um interessante jogo de palavras que exemplifica a sutileza do embate, no qual os insultos não são descarados - dentre estes a metáfora antissemita "almário de judeu" (VICENTE, 2002, p. 252). Diante das acusações, dentre elas colocar água no leite que vendia, Marta Gil se defende, estendendo ao contexto em que vivera a culpa: "todos fazem seu proveito"; viveu "em tempo de cobiça / cada tempo sua usança" (VICENTE, 2002, p. 252-253). Como o Lavrador, culpa o contexto, pecaminoso, pelos seus erros.

Dirige-se então ao Anjo, que a manda embarcar com o Diabo, por trazer os cestos carregados de pecados. Mas ela apela, persignando-se e invocando, sobretudo, a "virgem do rosairo": "fui vossa lavradora / em que pecasse algûa hora / venha a piadosa alçada" (VICENTE, 2002, p. 254). Invoca também a ajuda dos Anjos, mas não convence o Juiz. Então, rompendo as fronteiras entre o que está sendo representado e a circunstância da representação, apresenta o seu último argumento: "E este serão glorioso / nam é de justiça nam / mas todo mui piadoso / em que naceu o esposo / da humanal geração. / E a barca de Satam / nam passa hoje ninguém / e per força hei d'ir além / so pena d'escomunhão / que posta tem" (VICENTE, 2002, p. 255). Se não por merecimento próprio, pela piedade divina, materializada no Natal, estaria livre do Inferno.

O veredito do Anjo faz-nos pensar nos muitos lugares do Além, de que falamos atrás, retomados por Dante na Divina Comédia. O Anjo enfatiza o grande sofrimento que terá para purgar os pecados, o que não acontecera ao dar seu veredito ao rude Lavrador, indicando uma maior penalidade para a sagaz regateira: "purga ao longo da ribeira / segura de danação / terás angústia e paixão / e tormento em grã maneira /. / Isto até que o senhor queira / que te passemos o rio / será tua dor lastimeira / como ardendo em gram brasio / de fogueira (VICENTE, 2002, p. 255).

Então, como o Lavrador em seu discurso final, exproba a existência material, mas já agora enfatizando a conduta individual e o livre arbítrio contra os pecados: "Oh quem tal arrepender / tal maneira de penar / lá soubesse no viver / oh quem tornasse a nascer / por nam pecar" (VICENTE, 2002, p. 255). A pena é condizente com as faltas, maiores ou menores, praticados com consciência ou não. A esperta mercadora teria muito mais a purgar que o revoltado campesino.

O Pastor, que entra a seguir, é símbolo de ignorância e inocência, expressos pelo seu rústico linguajar e por aceitar, de início, o convite do Diabo para entrar em sua barca. Mas percebe o erro e lhe dirige uma série de insultos, através de termos que provocam o riso: "Sois buzaranha / e mais fede-vo-lo o bafo / e jogatais de gadanha / e tendes modão d'aranha / e samicas serei garfo" (VICENTE, 2002, p. 256). O cômico de palavras e de situação se consolida, para distensão dos espectadores diante de tema tão lúgubre como o julgamento pós-morte.

O Diabo tenta convencer o Pastor de que cometeu em vida muitos pecados, nem sequer sabia rezar o Pai Nosso. Mas o Pastor se defende, indicando inclusive a data que 
está sendo comemorada: "Nam podes nada fazer / na noite em que quis nacer / Cristo filho de David" (VICENTE, 2002, p. 258). E o acusador se espanta, com esse discurso elevado na boca de um rústico: "Quem te pôs no coração / falares cousa tam boa / que tu nam tens descrição?" (VICENTE, 2002, p. 258). Mais um indício do neoplatonismo vicentino, apontando para as reminiscências do mundo intelectível de Platão ou para o emergir da Graça que nos habita segundo Santo Agostinho.

Interrogado pelo Anjo, a quem considera "milhor artesão", isto é, melhor obreiro que o Diabo, o Pastor, confessando não saber de cor as orações, diz no entanto haver obedecido aos mandamentos divinos e acreditar na Igreja "assi junta / com paredes e telhados / alicéceres e furados / e nam curar de pregunta / e dar ò demo os pecados" (VICENTE, 2002, p. 259). Novamente a rusticidade risível nessa descrição material da Igreja...

Mas o Diabo o acusa de luxúria e de intenção de estupro, ao que ele responde: "que pecado se seguiu / pois nam houve concrusão?" (VICENTE, 2002, p. 259). E o Anjo o condena a purgar "ao longo do rio / em grão fogo merecendo", ao que ele, em sua lógica rude, pergunta; "E quando parte o navio? Senhor s'eu nam tenho frio / pera que hei d'estar ardendo ardendo?" (VICENTE, 2002, p. 260).

Enfim, novamente o tema da inconsciência tornando menos graves os pecados e a pena. O Pastor não tem a capacidade de reflexão do Lavrador e da Regateira sobre os enganos da existência material, e sequer apela para o Natal como meio de salvação. Aliás, dissera Jesus no Sermão da Montanha, segundo Mateus $(5,2)$ : "Bem aventurados os pobres em espírito, porque deles é o Reino dos Céus" (BÍBLIA, [1981], p. 1288).

Já a Pastora menina, sente mais temor do demo, "do îmigo", que da morte, e invoca proteção da mãe, tomando "a Deos por valedor" (VICENTE, 2002, p. 260). Desnorteada, porque pensava que "da velhice gouvira", isto é, gozaria, confiante de que não morreria por ser jovem, expressa o seu desespero: 'Nam sei quem m'há d'ajudar / nam sei quem m'há de valer / nam sei quem m'há de passar / nam sei se m'hão de matar / outra vez ou que há de ser" (VICENTE, 2002, p. 261). Através da figura retóricopoética da repetição - no caso, de quase o verso inteiro, variando apenas o final - sua angústia é representada de forma mais intensa. E a repetição é uma das figuras da presença, que "têm por efeito tornar presente na consciência o objeto do discurso" (PERELMAN; O.-TYTECA, 1996, p. 197).

Recusando-se a acompanhar o diabo, este tenta seduzi-la através de palavras carinhosas e galanteios - "filhinha", "Policena", "rainha llena", etc. (VICENTE, 2002, p. 261) -; são diminutivos, metáforas e adjetivos que se adequam ao seu discurso de sedução. E se mostra totalmente enamorado pela jovem, a quem promete ser amante discreto, uma das regras do amor cortês. Mas a jovem o esconjura e vai até ao Anjo, enquanto o Diabo se lamenta de não conseguir levar ninguém consigo, sequer pela adulação.

Ao Anjo diz ser religiosa, de conhecer a Deus, inclusive através de visões. Bem como de ir sempre à igreja e ter o prazer e a glória de "ouvir missa e o ver" (VICENTE, 2002, p. 262). O Anjo elogia o seu comportamento mas o Diabo a acusa de maledicência, gula e falsidade: "Era a mor mexeriqueira [...] golosa [...] refalsada e mentirosa" (VICENTE, 2002, p. 262-263). Diante disto, ela se defende usando como argumento a sua pouca idade, o que a faria menos responsável por seus atos: "Era ainda rapariga" (VICENTE, 2002, p. 263). E o Anjo sentencia: "Vai ao longo desse $\operatorname{mar}^{19}$ / 
que é praia purgatória / e quando a Deos ordenar / nos te viremos passar / da pena à eterna glória" (VICENTE, 2002, p. 263).

Aparece em seguida "um Menino de tenra idade", que chama a mãe para livrá-lo do "coco", isto é, do bicho papão. E começa a discutir com o Diabo em linguagem própria do universo infantil, apelando para os parentes como escudo, ao que este responde: em tom de zombaria: "Bé", repetidamente, a ponto de o Menino indagar: "Nam queres senam berrar?" (VICENTE, 2002, p. 264). Trata-se de uma onomatopeia, que evoca a representação do diabo como um bode, recorrente nas artes visuais do medievo.

O Anjo o chama como sendo um dos seus, pois Deus lhe fez "a mais profunda mercê / em idade de inocente / eu nam sei se sabe a gente / a causa por que isto é" (VICENTE, 2002, p. 264). Mateus $(19,14)$ tem a resposta, ao reproduzir o discurso de Jesus, censurando discípulos que às crianças repreendiam: "Deixai as crianças e não as impeçais de virem a mim, pois delas é o Reino dos Céus" (BÍBLIA, [1981], p. 1308). Portanto, a explicação dessa salvação imediata se encontra "num plano doutrinal e não moral”, como destaca José Augusto Cardoso Bernardes (2006, p. 299). Vale lembrar, com esse vicentista, que a Igreja considerava,

desde Santo Agostinho e de S. Tomás, que as crianças estavam isentas de pecado pessoal. E, assim sendo, bastava o baptismo para lhes assegurar a salvação, pois a ausência do sacramento os remeteria para uma espécie de limbo onde gozariam a felicidade natural (BERNARDES, 2006, p. 299).

Mas, mesmo aí, novamente se evidencia a questão da consciência ou não do pecado como base do veredito do Anjo, já que a criança, "em idade de inocente", apresenta grau nulo de responsabilidade. Não à toa, o Menino se coloca em pé de igualdade com o Parvo Joane, ao chamá-lo "o nosso Joane" (VICENTE, 2002, p. 264), sendo este um personagem do Auto da Barca do Inferno que também escapara do Inferno por sua ingenuidade.

O último réu é um Taful, a quem o Diabo saúda como "meu sócio e meu amigo" (VICENTE, 2002, p. 264). Traz consigo "flux dum metal" (VICENTE, 2002, p. 264), isto é, cartas do mesmo nipe, instrumento das jogatinas que fez em vida e que pretende continuar no pós-morte. Embora o Diabo o tenha como seu por esse vício, o Taful recusa-se a acompanhá-lo por ver o seu "mui mal sembrante" e considerá-lo "por da ré muito roim / e malino por avante" (VICENTE, 2002, p. 265). Então o Diabo indica-lhe os principais pecados, a descrença e as blasfêmias: "Mas tornemos a jogar / porque tenho saudades / de te ouvir arrenegar / e descrer e brasfemar / do mistério da trindade" (VICENTE, 2002, p. 265). Apresenta vários atos praticados pelo réu, renegando a Deus e zombando dos ofícios divinos e dos santos. Inclusive da data que se comemora no presente, o Natal, e suas oitavas. A resposta do Taful é um sofisma: "quem bem renega bem crê" (VICENTE, 2002, p. 265), expressão certamente usada no contexto cristão para significar que quem bem renega o Diabo, bem crê em Deus. Prática totalmente inversa à dele, em vida.

Dirige-se em seguida ao Anjo, em busca de piedade para si, reconhecendo-se "homem tam carregado" (VICENTE, 2002, p. 266). Imputa os seus pecados ao fato de "estar ocupado / na grã perda que perdia" (VICENTE, 2002, p. 266), isto é, por perder 
no jogo, pela má sorte. Mas o Anjo o condena, destacando as ofensas que fez ao Divino, sobretudo à Virgem: "Renegar tam feramente / da emperatriz dos céus / ó pranta de má semente / arderás no fogo ardente / com toda a ira de Deus" (VICENTE, 2002, p. 266). Destaque-se o emprego da metáfora, da planta e da semente, muito corrente na Bíblia, por exemplo em Lucas $(8,11)$, onde o a "a semente é a palavra de Deus" (BÍBLIA, [1981], p. 1354), que frutificará de acordo com os que a ouvirem e do solo em que se encontram. No caso, a semente a que se compara o Taful é outra, é a má semente de origem satânica.

O Taful lança mão do argumento final, o significado redentor do Natal: "Deus nam quis hoje nacer / por remir os pecadores?" (VICENTE, 2002, p. 266). Mas responde ironicamente o Anjo: "E pois que queres dizer / que só c'o seu padecer / se salvam renegadores?" (VICENTE, 2002, p. 266). De nada vale o argumento seguinte, em que lança a culpa dos seus atos na má sorte que o subjugava: "A perneta me forçou / que era senhora de mi" (VICENTE, 2002, p. 266). Trata-se de uma alegoria do destino, comparado a pessoa deficiente e certamente conhecida do auditório.

O Anjo entrega o Taful ao diabo, mas o réu ainda argumenta, apelando novamente para a data que está sendo comemorada: "Senhores / deste santo nascimento / nam terei alguns favores?" (VICENTE, 2002, p. 267) - apóstrofe que se dirige aos Anjos, mas também pode se estender ao auditório, fazendo-o participante do julgamento. Ao que o Anjo responde, encerrando o auto: "Tafules e renegadores / nam tem nenhum salvamento" (VICENTE, 2002, p. 267).

Como indica a rubrica final, os diabos saem da barca e levam o Taful, cantando uma cantiga "muito desacordada", isto é, desentoada ou sem sentido, e os Anjos "cantando levam o Menino". Última indicação que opõe os dois mundos, o do desacordo e o da harmonia celestial. Mas a rubrica também fala do auto Purgatório como uma "segunda cena", iniciada com o auto do Inferno. Diga-se de passagem que esses autos, ambos apresentando um julgamento após a morte, se distinguem pelo extrato social dos personagens, hegemonicamente medianos e urbanos neste e de extração mais baixa e campesina aquele, à exceção do Taful, cujas ações indicadas extrapolam o espaço campestre. Já na "terceira cena", isto é, no auto seguinte, de 1519 , o da Glória, os personagens seriam "dignidades altas".

\section{Considerações finais}

Vimos ser o auto que analisamos fundamentado na retórica judiciária, cujos elementos são observados na recriação vicentina de um julgamento, onde a acusação e a defesa se utilizam de provas, réplicas e/ou refutações, tendo em vista o veredito final. Como também que um tipo de discurso pode conter elementos de outros. Assim, se Gil Vicente recriou um discurso de predominância judicial, no entanto este se dirige a um auditório para o qual representa um conselho a ser seguido na existência terrena: a necessidade de ações virtuosas, de religiosidade e fé para o alcance do Paraíso celestial.

Sobretudo as virtudes teologais - fé, esperança e caridade - são destacadas e se concretizam no Natal, isto é, no nascimento do Messias, exemplo maior da caritas em sua entrega aos sofrimentos da encarnação por amor à humanidade, fornecendo-lhe um modelo e a esperança de redenção para a qual a contrição, a penitência e a fé são imprescindíveis. Maria é modelo de pureza e de fé inabalável, em sua submissão total 
aos desígnios divinos e no enfrentamento das dores disto advindas na existência terrena. Tal é a ótica cristã que perpassa o auto, que, como vimos ao tratarmos da inventio, era a dominante à época da escrita e representação da peça.

Destinado o auto a um público religioso e encenado na capela de um hospital em tempo de peste, a questão da salvação espiritual se fazia oportuna, optando o autor por apresentar, no julgamento após a morte, a esperança para o alcance da mesma, materializada na ideia católica de Purgatório. Tal via de redenção, tornada dogma pela Igreja, não destoaria da comemoração para a qual foi feita a representação: o nascimento do Redentor. Assim se explica a opção por uma cena lúgubre para as matinas do Natal, época tão festiva.

No exame das ideias de que disporia o dramaturgo para a inventio, isto é, a descoberta e seleção da matéria de acordo com o seu contexto de produção e de recepção e a conveniência à obra, destaca-se a concepção tripartite do Além - Céu, Inferno e Purgatório. Tais são os lugares de destinação das almas de acordo com seu merecimento, assente nas virtudes ou vícios praticados em vida, na obediência ou não aos Mandamentos mosaicos, e na fé ou sua ausência. Tal concepção se encontra não somente em discursos eclesiais, mas em muitas obras de arte do período, notadamente em pinturas, esculturas e obras literárias, por exemplo na Divina Comédia, do escritor florentino Dante Alighieri. Assim, dos séculos XII ao XVI muitas foram as formas de divulgação desse Além como um lugar de purgação, no qual a Igreja poderia ter ingerência através da venda de sufrágios e indulgências.

De posse desses elementos, Gil Vicente elaborou, em versos de métrica popular ou de arte menor - isto é, curtos e com predominância da redondilha maior ou heptassílabos - sua obra dramática, buscando a verossimilhança na apresentação dos personagens. Para tanto, lançou mão de linguajar e de figuras retóricas apropriados a cada situação, recorrendo por vezes à licença poética - por exemplo, nos raros momentos em que coloca palavras elevadas e cultas na boca de personagens rudes, com base nos conceitos de reminiscência platônica e de graça agostiniana. Não só a linguagem, mas também as noções religiosas e existenciais são condizentes com o extrato social representado pelos personagens. Dessa forma, a ignorância e a inocência em relação aos pecados são passaporte, senão para a salvação imediata, para o alcance da mesma após um período de purgação. O respaldo se encontra nos evangelhos, onde crianças e "pobres em espírito" têm destinação aos Céus, ao lado dos justos, isto é, dos virtuosos e obedientes aos Mandamentos.

Enfim, com o apoio da retórica, pudemos observar o trabalho do autor e a sua mestria na manipulação dos recursos de que dispunha para dar à luz uma de suas tantas incomparáveis obras. Nestas, o docere cum delectare se evidencia, por exemplo ao lançar mão da comicidade que leva os espectadores ao riso, maneira leve de se propagar ensinamentos, no caso teologais. Sendo representado o Diabo como figura grotesca e que provoca o riso, aliás imagem recorrente em muitas obras de arte do período, Gil Vicente releva a lei divina do livre arbítrio, que dá ao homem o direito de escolha entre virtudes e vícios na vida material, e, portanto, a responsabilidade pelos seus atos. $\mathrm{E}$ destaca o peso da consciência maior ou menor nas ações pecaminosas cometidas como decisivo para o alcance da maior ou menor pena no julgamento que seu auto nos proporciona. 


\section{Referências}

ALIGHIERI, Dante. A divina comédia. Trad. brasileira de José Pedro Xavier Pinheiro, ilustrações de Gustavo Doré, apostilas de R. Fornaciari com estudo de António Piccarolo. São Paulo: Leia, 1946.

ARISTÓTELES. Arte retórica e arte poética. Trad. António Pinto de Carvalho. Rio de Janeiro: Ed.Ouro, [s.d].

Ética a Nicómaco. Tradução de Leonel Vallandro e Gerd Bornheim. In: ARISTÓTELES. Metafísica: livros 1 e 2; Ética a Nicómaco e Poética. São Paulo: Abril Cultural, 1979.

BERNARDES, José Augusto Cardoso. Sátira e lirismo no teatro de Gil Vicente. 2 vols., 2. ed., Lisboa: Imp. Nacional - Casa da Moeda, 2006.

BÍBLIA. A Bíblia de Jerusalém. Ed. em língua portuguesa coord. Por Gilberto da Silva Gorgulho et alii. São Paulo: Edições Paulinas, [1981].

CAMÕES, José. Purgatório. Lisboa: Quimera, 1993.

CÍCERO, Marcos Túlio. De inventione: de la invención retórica. Ed. bilíngue com trad., introd. e notas de Bulmaro Reyes Coria. México: Universidad Nacional Autónoma do México, 1997.

LAUSBERG, Heinrich. Elementos de retórica literária. Trad., prefácio e aditamentos de R. M. Rosado Fernandes. 3. Ed. Lisboa: Fundação Calouste Gulbenkian,1982.

LE GOFF, Jacques. Além. In: LE GOFF, Jacques; SCHMITT, Jean-Claude. Dicionário temático do Ocidente medieval. Trad. coordenada por Hilário Franco Júnior. Bauru: EDUSC; São Paulo: Imprensa Oficial do Estado, 2002, v. 2, p. 21-34.

LUCIANO. Diálogo dos mortos. Introdução, versão do grego e notas de Américo da Costa Ramalho. Coimbra: Instituto Nacional de Investigação Científica, 1989.

MALEVAL, Maria do Amparo Tavares. O teatro. In: MONGELLI, Lênia Márcia de Medeiros; MALEVAL, Maria do Amparo Tavares; VIEIRA, Yara Frateschi. A Literatura Portuguesa em perspectiva, v. I: Trovadorismo. Humanismo. São Paulo: Atlas, 1992, p. 170-190.

Fernão Lopes e a retórica medieval. Niterói, RJ: EdUFF, 2010.

. Revisitando o Boosco Deleitoso na companhia de Gil Vicente. Colóquio Letras, n. 182, p. 9-20, 2013.

. "Gil Vicente e o drama litúrgico natalino: algumas considerações. Signum revista da ABREM, Fortaleza, v. 18, n. 2, p. 132-158, 2017 b. 
Pregação e(no) teatro. Mistérios da Virgem / Mofina Mendes. In: FERNANDES, Geraldo Augusto (org.). Temas e representações. Fortaleza: Grupo de Trabalho de Estudos Medievais da ANPOLL, 2020, p. 99-121. E-book.

Retórica e doutrinação no Auto da feira de Gil Vicente. In: Atas do XIII Encontro Internacional de Estudos Medievais: sobre margens, diversidades e ensino. Fortaleza: ABREM, UFBA (no prelo).

PERELMAN, Chaim; OLBRECHTS-TYTECA, Lucie. Tratado da argumentação. A nova retórica. Trad. de Maria Ermantina Galvão G. Pereira. São Paulo: Martins Fontes, 1996.

QUINTILIANO, Marco Fabio. Instituciones oratorias. Alicante: Universidade Biblioteca Virtual Miguel de Cervantes, 2004.

SCHMITT, Juliana. O estudo das danças macabras medievais: entre o visível, o oculto e o destruído. Ara, [São Paulo], n. 3, p. 233-253, 1017.

TRIFILETTI, Luca. Recepção da Divina comédia em Portugal. Veneza: Università Ca'Foscari, 2016.

VICENTE, Gil. Obras completas. Vol. 1: Obras de devaçam. Anotadas por Marques Braga. Coimbra: Imprensa da Universidade, 1933.

As obras de Gil Vicente. Direcção científica de José Camões. Vols. 1 e 2. Lisboa: Imprensa Nacional - Casa da Moeda, 2002.

\footnotetext{
${ }^{1}$ Desenvolvemos maiores considerações a propósito da vida e obra de Gil Vicente em Maleval (1992).

${ }^{2}$ Provavelmente representado na capela do Hospital de Todolos Santos em Lisboa, espaço adequado à encenação de obras de devoção, pela topografia da mesma, indicada por Mário Carmona (apud CAMÔES, p. 4) "os doentes podiam assistir das camas à missa e, quem sabe, ver ou ouvir o auto" (CAMÔES, 1993, p. 4).

3 Temos observado esta preocupação com a morte e com a vida após esta, e daí, a apregoação da necessidade de uma vida virtuosa para o alcance da salvação eterna, nos autos natalinos de Gil Vicente, em algumas publicações. Ver, por exemplo, "Gil Vicente e o drama litúrgico natalino" (MALEVAL, 2017), "Pregação e(no) teatro. Mistérios da Virgem / Mofina Mendes" (MALEVAL, 2020), bem como a que se encontra no prelo, "Retórica e doutrinação no Auto da feira de Gil Vicente" (no prelo)

${ }^{4}$ José Camões (1993, p. 3) acrescenta a estes o Auto da Alma que foi, como o da Glória, representado na Páscoa, festejando "a redenção das almas pela morte de Cristo".

${ }^{5}$ Retomamos aqui algumas considerações desenvolvidas em estudos anteriores, como por exemplo em Maleval (2010, p.74).

${ }^{6}$ Grafamos em latim porque essas partes da retórica foram difundidas através da língua latina, e não da grega, no Ocidente, principalmente através das obras de Cícero - por exemplo De inventione (1997) - e Quintiliano (2004).

${ }^{7}$ Desenvolvemos este assunto em obras anteriores, por exemplo em Maleval (2010. p. 78).

${ }^{8}$ Os lugares podem ser locus a re, a persona, a loco ab instrumento, a causa, a modo, a tempore.

${ }^{9}$ Como é matéria do auto, vale serem lembrados, já que são hoje desconhecidos ou ignorados por muitos: amar a Deus sobre todas as coisas, não cometer idolatria, não usar o nome de Deus em vão, guardar o Dia do Senhor, honrar pai e mãe, não matar, não cometer adultério, não roubar, não prestar falso testemunho e
} 
não cobiçar os bens alheios. Servem de base, com ligeiras variações, tanto ao judaísmo, século X a.C., quanto às igrejas depois de Cristo: católica, século IV, ortodoxa, século XI, e protestante, século XVI.

${ }^{10}$ Estudamos esse auto em trabalho que se encontra no prelo (Atas do XIII EIEM).

${ }^{11}$ Nasceu por volta de 125 e faleceu depois de 181. Trocou sua terra natal, a Síria, pela Grécia, viajando pela Europa, Gália e Itália, onde ganhava a vida como advogado, tornando-se orador de sucesso. Mas trocou esse sucesso pela filosofia, voltando a Atenas, onde escreveu suas obras satíricas em prosa.

${ }^{12}$ Cf., a propósito, o estudo de Juliana Schmitt (2017) sobre as danças macabras.

${ }^{13}$ Tratamos desse assunto em um livro que se encontra no prelo (EdUFF), intitulado $O$ teatro medieval $e$ seus congêneres em Santiago de Compostela (séculos XII-XIII).

${ }^{14}$ Por exemplo, no Sermão de Abrantes, sobre o qual publicamos recentemente um estudo (MALEVAL, 2020) que o focaliza, juntamente com o Auto dos Mistérios da Virgem ou da Mofina Mendes. No Auto da Alma, que analisamos comparativamente ao tratado de edificação espiritual intitulado Boosco Deleitoso (MALEVAL, 103), focaliza-se a dura caminhada existencial entre tentações demoníacas e conselhos do Anjo, com a contrição final da Alma, que na Igreja, "estalajadeira pera refeição e descanso das almas que vão caminhando para a eternal morada de Deus" (VICENTE, 2002, 189), é redimida pela Paixão de Cristo.

${ }^{15}$ José Camões considera ser o Auto da Fama, caso a indicação temporal da rubrica esteja correta - 1510, data contestada por muitos especialistas -, o auto em que "a língua portuguesa é, pela primeira vez, língua pastoril na figura da Fama pastora" (CAMÕES, 1993, p. 9).

${ }^{16} \mathrm{O}$ saiaguês era antigo idioma rústico procedente de Saiago, no Reino de Leão.

${ }^{17}$ Este fato nos evoca o coro do teatro grego, que se apresentava em seguida ao prólogo - párodo - e entre os episódios - estásimos -, após os quais vinha o epílogo.

${ }^{18} \mathrm{Na}$ interpretação de José Camões (1993, p. 3), possivelmente o Lavrador e o Pastor teriam por nome Gil, dado que as referências que fazem a este nome podem significar referências a si próprios : "a Gil fiz todo repairo" (VICENTE, 2002, p. 250); “e tudo s'a Gil fará [...\} (VICENTE, 2002, p. 258).

${ }^{19}$ Refere-se ao mar, e não ao rio, como antes fizera. 